\title{
Investigation of Parents' Views Regarding the Recognition and Education of Specially Talented Individuals in Early Childhood Period
}

\author{
Mesut AŞIK ${ }^{1 *}$, Hikmet ZELYURT ${ }^{2}$ \\ ${ }^{1}$ 2Bilim Uzmanı. Öğretmen, MEB-Malatya/Yeşilyurt RAM Müdürlüğü, Türkiye, \\ Dr. Öğretim Üyesi, İnönü Üniversitesi, Eğitim Fakültesi, Temel Eğitim ABD, Okul Öncesi Eğitimi Bilimdalı, Türkiye,
}

\begin{abstract}
This study was conducted with the parents of 30 children aged between 7 and 15 years with a mean age of 9.47 who were officially diagnosed as gifted individuals. Parents' views on recognizing and training gifted individuals in early childhood were examined. It is aimed to determine the characteristics of gifted individuals in early childhood and to reveal parental experiences about their education. Parents of students attending Malatya Science and Art Center (BILLSEM) participated in this research. Semi-structured interviews were conducted with 30 parents who voluntarily participated in the study. In this study, which was carried out with a phenomenological design, which is one of the qualitative research methods, a transcript of each interview was written from the audio recordings for data analysis. The answers were grouped under the main coding title and categorized. Subcoding was obtained from the categorized responses. In the sub-coding, similar expressions gathered under one heading were listed and the final tables were obtained. The tables were analyzed and the findings were obtained. The results obtained from the findings were summarized and interpreted in line with the sub-problems of the research. From the results of the research, it is understood that the most distinctive features of gifted individuals in early childhood are the advanced level in learning, motivation and language-speaking. In order to recognize the child in the early period, giving importance to the education of parents and preschool teachers, directing them to intelligence tests and developing a diagnostic program for these children are among the findings.
\end{abstract}

Keywords: Early Childhood Period, Specially Talented Individual, Knowing the Individual, Identification, Parents' opinions.

\section{INTRODUCTION}

In early childhood, family is the most important living space for children. It is natural, familiar and inevitable, of course, for young children to grow up in the family, as the perfect example of the world. Children are born dependent on their parents; With the intensive support and education of adults, they can only continue their first years of life. They learn language, basic skills, social norms and social competences in the family, develop personality structures, character traits, thinking styles, ways of experiencing, role expectations and attitudes (Schneewind, 1991). In this way, the foundations of development are laid for the child in the early childhood period in the family.

In addition to the psychological development of the child, the family stands out as an effective socialization center where the individual is shaped and guided in terms of socioeconomic and physiological development. At the same time, prelearning and education is provided by teaching the democratic characteristics of the family. In order to support the development of individuals in the early childhood in line with concepts such as tolerance, love and endurance, transformation should be realized as a lifestyle by democratic families who do not exert pressure. Positive relationships are displayed in democratic families, where social competence and self-efficacy are seen most prominently. (Çullu and Samancı, 2016; Bolat and Yelken, 2020)
However, there is no such thing as a single type of family: on the one hand, historical and sociological studies have shown that there are many different types of families past and present (Rosenbaum, 1982; Weber-Kellermann, 1987). On the other hand, every family is unique. Unique system features, structures, relationship attributes, interaction patterns, rules, etc. has. Each individual family is perfect, just as its members are unique individuals.

Accordingly, there is no such thing as a "general family" experience. Each child in early childhood gains different experiences from their family. Each child interprets the behavior of their parents, siblings and relatives differently. She

Corresponding Author e-mail: mesut.pdr.1979@gmail.com https://orcid.org/0000-0001-9336-4169, ,

How to cite this article: AŞIK M, ZELYURT H, (2021). Investigation of Parents' Views Regarding the Recognition and Education of Specially Talented Individuals in Early Childhood Period. Pegem Journal of Education and Instruction, Vol. 11, No. 4, 2021, 44-52

Source of support: Nil

Conflict of interest: None.

DOI: $10.47750 /$ pegegog. 11.04 .05

Received: 24.12 .2020

Accepted: 24.06.2021 Publication: 01.10.2021 
grows up in a social environment where her caregivers respond individually to their unique characteristics, needs, emotions, activities, verbal and non-verbal messages. On the one hand, it is shaped by the family in its behavior and experiences, on the other hand, it shapes its social environment with its reactions. Due to the uniqueness of the life context of each child in early childhood and their families, generalizations for young children are extremely limited. (Markefka and Nave-Herz 1989; Paetzold and Fried 1989; Schneewind 1991 and Textor 1991)

It depends on parents' behaviors in meeting the needs of the gifted child to ensure the development and life satisfaction of the child as a happy individual. Therefore, parents play an important role in the development and education of individuals with special talents. It is seen that parents whose children are gifted need more awareness levels to prevent their education and possible problems. (Çavuşoğlu and Semerci, 2015)

As a group that is expected to play an active role in shaping our future, talented individuals should be guided in the most accurate way in line with their needs starting from early childhood. Raising specially gifted children from early childhood without adopting a correct education style with democratic universal gains may cause them to be out of the desired behavior and attitude in the future. The experiences and trainings thought for the student will shape the future life of the child. Therefore, the family has a high impact and importance in the lives of gifted children who have more than one needs and characteristics. (Bolat and Yelken, 2020)

According to Güler (2012), subjective behaviors of parents are reflected on children in child education. Thus, the attitudes and behaviors exhibited by the parents can reflect positively or negatively on the child's mental, physical, social, emotional, psycho-motor and personality development. Beginning from the prenatal period, the fact that the child's developmental homes are noticed or known by the mother and father will contribute to how to behave towards the child. The fact that parents do not notice or know the developmental characteristics of their children causes them to be insufficient in how they can contribute to them (İpek, 2019).

Here, the studies of getting to know the individual gain importance. As much as possible, the individual should be known in all aspects. The main goal of the activities carried out to get to know the person in all aspects is to support the person to know himself. As an individual, children's interests, developmental differences, learning abilities and needs may differ from each other. One of the most obvious goals of school and education processes is for children to benefit from learning environments in the most profitable way. In order to achieve this, first of all, children should be recognized (Yeşilyaprak, 2006). Besides parental education for young children, pre-school education provides the most important learning opportunity. Education and training activities carried out in early childhood are effective in child development as a method, discovery and development of talents (Solzbacher \& Behrensen 2010).

The institutions where children meet face to face after they are born are kindergartens. In this process, child recognition activities are among the duties of the preschool teacher. A child starting kindergarten can usually receive training from the same teacher. The child and the teacher can be together all day and have the opportunity to individually apply the methods of getting to know the individual for him. The period in which the child develops quite rapidly is preschool. For this reason, the methods of getting to know more than one individual, which are carried out in pre-school education institutions and meticulously recorded, will make a positive contribution to the child's recognition and education in all its aspects. Developments that are not recorded can easily be overlooked (Kuzgun, 2003; Denizkan, 2007; Heller \& Schofield, 2008).

According to Horsch et al. (2006), the characteristics of gifted children in the preschool period are high learning power and quick grasping ability. Therefore, educating and raising awareness of families of gifted individuals in the earliest period is an urgent issue. While the role of the family or school-family cooperation is undeniable even in the education of non-gifted individuals, it is more evident in the education of gifted individuals. In the earliest period, the people and institutions that parents can receive information, support and training from are very limited. Therefore, first of all, it is necessary to carry out studies on the level of awareness of families. The opinions of experienced parents gain importance in order to get to know children in the early period and take steps to meet their needs.

\section{Method}

In this section, information about the method of the study is given. Explanations about the research model, study group, data collection tools, data collection and analysis are presented.

\section{Research Design}

In this study, the views of parents with gifted children on early diagnosis and education were examined. It is a qualitative research that deals with the meanings that individuals create with their experiences in the process, their comprehension, perception of the world, and how they perceive the events that occur (Merriam, 2013). In this study, it was studied how the parents described the existing phenomenon in detail. Phenomenology was used as the study design (Tanriöğen, 2012). In this design, it is aimed to determine the problem and to comprehend the basic phenomenon in detail. The research questions are aimed at enabling the participants to express their experiences widely. In addition, it is a method used to collect data based on the discourse of a small number of people, to describe the data using text analysis, to analyze 
the data according to the themes, and to interpret the findings in a broader sense (Creswell, 2013; Yıldırım \& Şimşek, 2011).

\section{Study Group}

Participants are the parents of 30 children registered to Malatya Science and Art Center Directorate (BİLSEM) in the 2019-2020 academic year and diagnosed as gifted individuals within the framework of official recognition by RAM. Demographic information of the participants is presented in Table 1.

\section{Data Collection Tools}

An in-depth search was made in the literature on the subject of the study. As a result of the scanning, a semi-structured interview form was drafted for the interviews. The draft form presented to three faculty members from İnönü University, Faculty of Education, Department of Educational Sciences and Basic Education was developed by taking the opinions of the faculty members. Afterwards, the semi-structured interview form was applied to five parents as a pilot study. The data obtained from the pilot study were shared with the faculty members and the final shape was given by making minor adjustments. The developed interview form consists of two parts. In the first part, there are questions about the personal information of the participants and their experiences about professional, academic and gifted individuals. In the second part, there are 10 semi-structured questions to determine the views of parents on the recognition and education of gifted individuals in early childhood.

Table 1: Demographic information of the participants

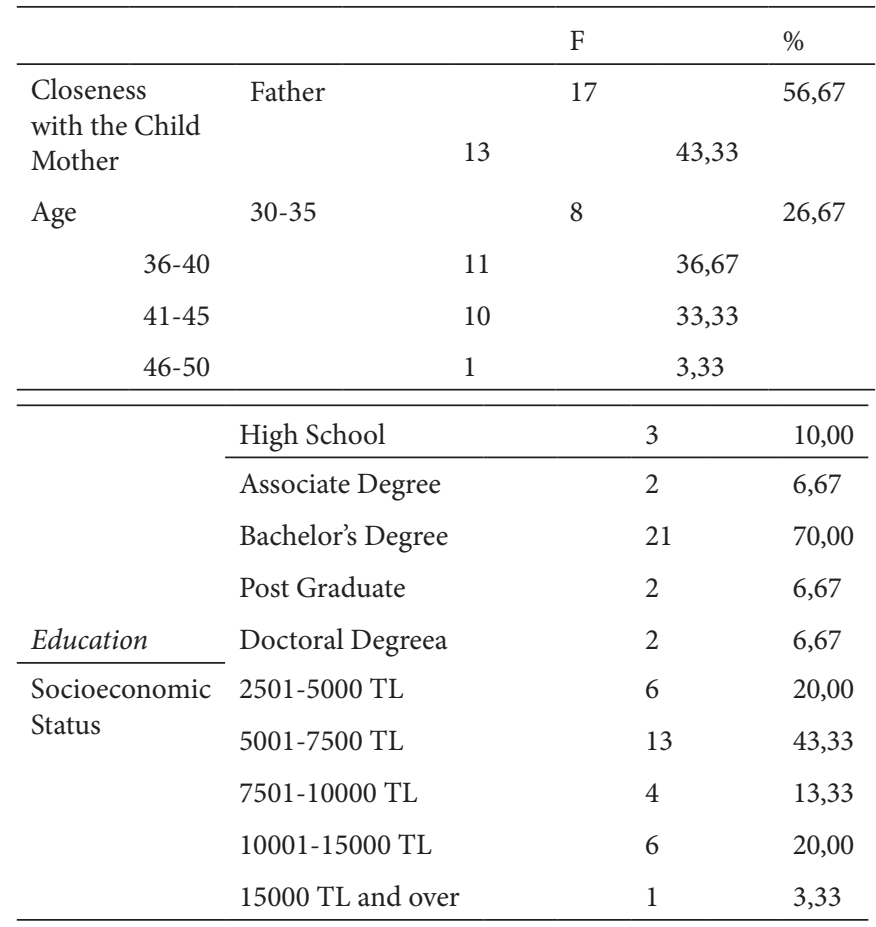

\section{Data Collection}

First of all, within the scope of obtaining legal permissions for the realization of the study, the approval dated 08/06/2020 and numbered E.34811 was obtained from İnönü University. Before starting the interviews with the parents, an appointment was made with the BİLSEM Director and the guidance teacher and preliminary interviews were held with them. As a result of the negotiations, it was decided to work on the course entry-exit hours of the primary school students. The aim here is to observe the principle of proximity to the early childhood period of gifted individuals. Thus, it was ensured that the interviews were conducted with the parents of the gifted individuals closest to the early childhood period. On a daily basis, parents were informed about the study between the students' entry and exit hours. A total of 108 parents were informed. As a result of the information, interviews were conducted with a total of 30 parents who were randomly selected among 46 parents who wanted to participate in the study voluntarily. Parent interviews were conducted at BİLSEM guidance service, Yeşilyurt RAM and Yeşilyurt Sümer Primary School. Audio recordings were taken during the interviews. The interviews lasted a total of 8 hours 54 minutes 44 seconds. The average duration of a call is 17 minutes 49 seconds. The study was conducted in June 2020.

\section{Data Analysis}

The coding method was used for the analysis of the data. The transcript of each interview was written from the audio recordings. The answers obtained were transferred to the Word document. Main coding and subcoding were formed from the responses. In the subcoding, expressions close to each other formed frequencies and percentages (Saldana 2019 trans. Tüfekçi, Şad and Akcan). Parents' opinions were analyzed by interpreting the findings. In order to ensure validity and reliability, the transcripts were given to another expert and coded without sharing the personal information of the participants. The similarity between the two encodings is $92.87 \%$.

\section{FINDINGS}

When Table 2 is examined, the most important difference with $27.83 \%$ of the answers given by the parents in the mentioned total frequency is that the main topic related to learning. Afterwards, 22.63\% motivation, $11.30 \%$ language and speech, $10.43 \%$ academic, $6.96 \%$ asking questions, $5.22 \%$ Imagination, $5.22 \%$ Stubbornness, $2.61 \%$ painting, situation and other main headings. According to the participating parents, it can be said that individuals with special talents differ from other children in early childhood as a willingness to learn and learn quickly. Examples of the opinions expressed by some participating parents regarding the characteristics of individuals with special talents in early childhood are presented below. 
Table 2: Characteristics of gifted children

\begin{tabular}{lll}
\hline & $F$ & $\%$ \\
\hline Learning & 32 & 27,83 \\
Motivation & 26 & 22,61 \\
Language and Tolk & 13 & 11,30 \\
Academic & 12 & 10,43 \\
Ask a Question & 8 & 6,96 \\
Imagination & 6 & 5,22 \\
Stubbornness & 6 & 5,22 \\
Picture & 3 & 2,61 \\
Emotion-State and ather & 9 & 7,83 \\
\hline
\end{tabular}

Table 3: Discovery of gifted individuals

\begin{tabular}{lll}
\hline & $F$ & $\%$ \\
\hline Education & 19 & 35,85 \\
Guiding Intelligence Test & 14 & 26,42 \\
Method & 13 & 24,53 \\
\hline
\end{tabular}

- KE 5: Reading and writing was self-taught. He was constantly asking about the planets. He was asking a lot of questions about substances. He was asking everything about life.

- KE 14: He was very curious. His awareness was very high. He would ask a lot of questions. His painting ability and interpretation were high. He learned to read and write on his own. He had a strong sense of humor and humor.

- KE 21: He devotes special time internally to the areas he is interested in. Your perceptions are very clear and versatile. He always wants to do something without getting tired.

Parents' answers to the question of what can be done to discover talented individuals in early childhood According to Table 3, family and teacher education is the most important factor in discovering individuals with special talent in early childhood with $35.85 \%$. Raising the awareness of the family and having the pre-school teacher equipped are among the main topics of education. Then, as another main topic, there is a referral to intelligence test with $26.42 \%$. In the main heading of the intelligence test guidance, there are expressions such as conducting intelligence tests within the scope of BİLSEM diagnosis before school, performing a test application by an expert by referring to RAM, and performing tests within the scope of the follow-up system in family health centers. The last main topic is about the method with $24.53 \%$. In the main title of method, some techniques for preschool teachers are mentioned. These techniques are: observation, tracking, monitoring, looking at comprehension ability, discovering a single special feature, understanding from behavior, dealing with the individual and determination of the teacher.
Table 4: Education of gifted individuals

\begin{tabular}{lll}
\hline & $F$ & $\%$ \\
\hline Quality Time & 28 & 29,17 \\
Play & 26 & 27,08 \\
Artistic, Sports and Cultural & 11 & 11,46 \\
School Course Activity & 13 & 13,54 \\
Book/Story & 10 & 10,42 \\
Not doing a special study & 8 & 8,33 \\
\hline
\end{tabular}

According to the parents, with the aforementioned techniques and methods, the results stated as a talented individual can be discovered in early childhood. Examples of the opinions expressed by the participating parents about what should be done to discover individuals with special talents in early childhood are presented below.

- KE 6: Mom and Dad may not exactly notice, but the teacher can definitely derive something from the child's behavior.

- KE 16: BILLSEM diagnosis and selection process can be brought forward. Even in the nursery, tests can be done to determine the intelligence of children.

Table 4 shows what parents have done about the education of specially gifted individuals in the early childhood period. Accordingly, spending quality time with $29.17 \%$ emerges as the first main topic. In the main headline of spending quality time, family members' interest and education, lots of talking and spending more time stand out as sub-headings. After the main title of spending quality time, it gets games with $27.08 \%$. All games referred to as games here are mind and attention enhancing. After the game, $13.54 \%$ school / course / event main title is replaced. Afterwards, $11.46 \%$ artistic, sportive and cultural studies, $10.42 \%$ book / story reading, narration and completion studies, and lastly, $8.33 \%$ is about not doing a special work. It can be said that the parents of individuals with special talent in early childhood carry out enriched mental and academic studies with quality time. In addition, it is understood that artistic, sportive and cultural studies are not emphasized. Some of the opinions expressed by the participating parents on what is done for the education of individuals with special talents in early childhood are presented below.

- KE 7: We read a lot of books. We kept it away from 3T televisions, tablets, phones. We did not allow screen exposure. Apart from that, we talked a lot. We talked a lot to boost cognitive functions. We sent him to a chess and workshop course at the age of 4 .

- KE 15: I bought educational materials for my specially gifted child. Aimed at developing attention. We let them dream a lot, we were never prevented. Our elders supported us, grandmothers, grandmothers and grandparents constantly read and told books and told stories. 
Table 5: Activities for talent areas

\begin{tabular}{lll}
\hline & $F$ & $\%$ \\
\hline General Ability & 33 & 37,5 \\
Cultural & 15 & 17,05 \\
Sport & 13 & 14,77 \\
Visual Arts & 11 & 12,50 \\
Music & 9 & 10,23 \\
Technology (other) & 5 & 5,68 \\
Not doing a special study & 2 & 2,27 \\
\hline
\end{tabular}

Table 6: Ensuring the teacher's training competence

\begin{tabular}{lll}
\hline & $F$ & $\%$ \\
\hline Education & 30 & 52,63 \\
Personal Development and Motivation & 15 & 26,32 \\
General Politics and Program & 11 & 19,3 \\
No Idea & 1 & 1,75 \\
\hline
\end{tabular}

- KE 29: I have read books since the age of eight months. While in the womb I talked a lot, talked to others. I played lots of games for him to learn the numbers. I reinforced their knowledge by sending it to kindergarten for 3 years. We played intelligence games. We gave great importance to feeding at the age of 1-2.

In Table 5, the responses of the parents regarding the studies carried out by the specially talented individual and the parents in general abilities, sports, visual arts, cultural or other fields in the early childhood period are given. When the findings are examined, it is seen that the most studies on general ability with $37.50 \%$ of individuals with special talents were carried out by parents in early childhood. Afterwards, it is understood that cultural activities were carried out with $17.05 \%$, sports with $14.77 \%$, visual arts with $12.50 \%$, music with $10.23 \%$ and technology with $5.68 \% .2 .27 \%$ of parents stated that they did not conduct a special study. The technology title with $5.68 \%$ emerged outside of the areas of skill asked by the researcher. Some of the views expressed by the participating parents about what was done by gifted individuals in the early childhood period according to their ability areas are presented below.

- KE 3: We did more sports and mental work. We have art and paint at home. Culturally, cinema and theater.

- KE 6: We directed more to sports due to the difference in their behavior. We tried to create different activities ourselves at home.

- KE 14: We put a lot of emphasis on mental studies such as attention tests and mind games. We sent it to the painting, music and drama course.

As can be seen in Table 6, parents 'opinions on how to ensure the teachers' ability to provide education in the
Table7: Availability of physical facilities and materials

\begin{tabular}{lll}
\hline & $F$ & $\%$ \\
\hline Insufficient & 17 & 53,13 \\
Partially Sufficient & 7 & 21,88 \\
Sufficient & 6 & 18,75 \\
No Idea & 2 & 6,25 \\
\hline
\end{tabular}

early childhood period are education with $52.63 \%$, personal development and motivation with $26.32 \%$, and general policy and system at $19.30 \% .1 .75 \%$ of the parents did not express an opinion on this issue. Some of the parents' views on what needs to be done to ensure the teacher's competence to provide education are presented below.

- KE 3: I think they should get practical training. They need to be subjected to practical training and practical exam, not theoretical.

- $\quad$ KE 7: They should be informed about it. They must educate themselves. Before school, gifted people should be a minor.

- KE 8: Foreign sources should be followed during the in-service training seminar period. It is necessary to transfer professional experience from teachers who have trained special talented individuals.

- KE 19: It must definitely do research and develop individually. There should be a general policy, everyone should go through this template and then take these children into their hands. It should be systematic, not left to chance.

In Table 7, parents' views on the availability of toys, materials, books and physical conditions in preschool institutions for children with special talents in early childhood are given. When the data obtained are examined, it is understood that the opinions of parents on the availability of gifted children in terms of equipment and physical conditions in the preschool institution of specially gifted individuals in early childhood and their education have emerged. Accordingly, 53.13\% insufficient, $21.88 \%$ partially sufficient and $18.75 \%$ sufficient statements were given. In addition, with $6.25 \%$, the parents did not express my opinion. Some of the parental views about the availability of physical and materials in the preschool institution are given below.

- KE 2: There should be material for them. It must be a conscious teacher.

- KE 4: It was not enough at that time.

- KE 8: Not all possibilities are the same. We sent it to two different public schools, one was very good and the other was not.

- KE 19: Of course not enough, we worked from completely separate sources.

As seen in Table 8, with the order of parents' expectations and suggestions regarding the diagnosis and education of 
Table 8: Parents' expectations and suggestions

\begin{tabular}{lll}
\hline & $F$ & $\%$ \\
\hline $\begin{array}{l}\text { Preschool Education Politics and Program for } \\
\text { Specially Talented Child }\end{array}$ & 40 & 49,38 \\
Erken Tanılama ve Eğitim & 21 & 25,93 \\
Early Diagnosis and Education & 12 & 14,81 \\
Family Education & 8 & 9,88 \\
\hline
\end{tabular}

gifted individuals in early childhood, $49.38 \%$ preschool education policy and program for gifted children, 25.93\% early diagnosis and education, $14.81 \%$ teacher education and family education with $9.88 \%$ are the main topics. Some of the expectations and suggestions of parents regarding the recognition and education of gifted individuals in early childhood are presented below.

- KE 3: First of all, these children should be recognized, not excluded, but earned. A separate study should be done for these children.

- KE 15: I wish BİLSEM was in pre-school period. It would be better to be detected at 4 and 5 years old

- KE 16: Exploring in pre-school. Discovery position is provided by empowering preschool teachers in schools.

- KE 24: Sports, painting and music should be emphasized before school. These trainings should be given by experts in their field with material support. Generally talented individuals can be supported in different materials, and experts should provide training with materials such as chess and tangram. It would be good to open a separate school.

- KE 30: I think all teachers should get education starting from pre-school. They should differentiate their activities by considering individuals with special talents. Family trainings should be provided.

\section{Discussion}

As can be seen in Table 2, the distinguishing features of gifted children in early childhood are faster learning and willingness to learn, according to their parents. Horsch et al. (2006) also state high learning and quick comprehension capacity among the characteristics of gifted children in this period. On the other hand, Arnold and Preckel (2011) refer to extraordinary speech development, verbal power and rich vocabulary that are unusual for their peers.

According to Table 3 , the views of parents on what can be done to discover gifted children in the early period are related to education, orientation to intelligence test and method methods. A number of techniques have been mentioned for pre-school teachers regarding method methods. These techniques are: observing, following, watching, looking at comprehension ability, discovering a single special feature, understanding from behaviors, dealing with the individual and teacher's determinations. According to the parents, a gifted individual can be discovered in early childhood with the aforementioned techniques and methods. In the literature, if a child is assumed to be intellectually gifted, it is recommended to use an intelligence test to diagnose it Preckel \& Brüll (2008). In the theme of directing parents to intelligence test, results emerged that children should be tested by BILLSEM/RAM and thus early diagnosis should be made.

As can be seen from Table 5, what is done by parents regarding the education of children in the early period is primarily play after spending quality time. Studies such as school, courses and activities come after quality time and play. Finally, parents mentioned artistic, sportive and cultural activities. It can be said that in the early childhood period, the parents of gifted individuals spend quality time with their childhood and carry out enriched mental and academic studies. In addition, it is seen that parents do not give weight to artistic, sportive and cultural activities. In the study of Preckel \& Vock (2013), it was stated that gifted children can only benefit from systematic and categorized support practices during school years, and within the scope of support approaches to the development of gifted children;

$>$ Individualization and Integration,

$>$ Group and Individual support,

$>$ Acceleration and Enrichment,

$>$ It refers to differentiation or curriculum change.

It is emphasized that the application of the aforementioned systematic studies for gifted children at school age in early childhood may be partially beneficial. Because normal preschool institutions support gifted children in early childhood with inclusive education method. These socially focused institutions do not treat gifted children in separate groups, but instead support them with other children by considering all their interests and developmental needs broadly (Ruckdeschel 2017).

As seen in Table 6, the parents' views on how to ensure the competence of the pre-school teacher who will teach the gifted child are unanimously stated that sufficiency can be achieved in this regard with education. They then emphasize personal development and motivation. Finally, they agree on the development of a general policy and program on this issue. Early childhood education institutions are important learning places for young children and have a significant impact on child development and the recognition and development of talents (Solzbacher \& Behrensen 2010). Individual support in preschool or child care institutions allows all children to develop their potential, including special talents, if they take into account the various abilities of children (Koop, 2017).

In Table 7, parental views on the availability of recognition and education in terms of equipment and physical conditions in the preschool institution are given. Accordingly, the results obtained are that the equipment and physical conditions are 
thematized as insufficient, partially sufficient and finally sufficient. Parents think that the equipment and physical conditions for the recognition and education of children are unsuitable.

Educational institutions for children in early childhood should be equipped in line with the needs of students. Richly equipped preschool institutions have a positive effect on the teacher-child relationship. In this way, besides creating livable education areas, education will be supported by removing disruptive factors. During this period, children are curious and inquisitive. It is necessary to provide educational environments that will meet the curiosity motives and needs of children. In the study conducted by Güleş (2013), preschool teachers express their views on the improvement of physical and environmental norms in their institutions (Özkubat, 2013).

The expectations and suggestions of parents regarding the diagnosis and education of gifted children in the early period are presented in Table 8 . Nearly half of the statements given by the parents on the subject are in the direction of developing a pre-school education policy and program for these children. Another issue addressed is the issue of early diagnosis and education. Emphasis was placed on the importance of teacher education and family education. Parents also emphasize the need to develop an education policy and program on the subject. Emphasis is placed on early diagnosis.

Intelligence is a measure that defines individual performance relative to the average developmental level of all peers. It develops at different rates in children. This is especially true for preschoolers (Koop \& Müller, 2010). From the perspective of inclusive education, supporting gifted children becomes a unique task of every preschool education center. This claim can be met as much as possible with a quality claim that every nursery should feel compelled to. To support each child entrusted to him on the basis of his level of development and according to the next development area. The diagnosis and education of gifted children is based on the general principles of good education practices in preschool centers (Koop \& et al. 2010).

\section{ConCLUSION}

In this study, which we conducted on what is done by parents to recognize and educate the gifted individual, the advanced levels of gifted children in learning faster in the early period, language-speaking and motivation have emerged. The views of the parents on the discovery of children are about the education of the preschool teacher, the education of the family, the orientation to the intelligence test and the development of a method or program for diagnosis in this period. A number of techniques have been mentioned for preschool teachers to help parents get to know the child. These techniques are: observing, following, watching, looking at comprehension ability, discovering a single special feature, understanding from behaviors, dealing with the individual and teacher's determinations. According to the parents, a gifted individual can be discovered in early childhood with the aforementioned techniques and methods.

It is the first quality time spent by parents for the education of their children. Then comes the game. When the literature is examined, some types of games strengthen the basic functions of the brain and thus form the emotional basis of children's cognitive development. Other types of games strengthen language development and memory (Knudsen, 2019). The importance of school, course and activity activities is mentioned. Finally, artistic, sporting and cultural studies are carried out. It is seen that parents mostly spend quality time with their childhood and carry out enriched mental and academic studies. In addition, it is understood that artistic, sportive and cultural studies are not given weight.

In terms of parents, preschool teachers are insufficient in the education of their gifted children. There are parents who state that it is partially sufficient. Only $1 / 5$ of the parents say that their pre-school teachers are sufficient to educate the gifted child. It is stated in the opinions that the diagnosis of children in the earliest period and the development of "general policy and system or program" for education. It is understood that the parents expressed an opinion that the teacher was insufficient in providing education. For example, a parent states:

Foreign sources should be followed during the in-service training seminar period. It is necessary to transfer professional experience from teachers who have trained special talented individuals. Another's opinion is as follows; It must definitely do research and develop individually. There should be a general policy, everyone should go through this template and then take these children into their hands. It should be systematic, not left to chance.

Parental views on the availability of educational institutions for recognizing and training gifted children in terms of physical facilities and equipment are insufficient, partially sufficient and finally sufficient. It is understood that parents think that the equipment and physical conditions of preschool institutions are unsuitable. In the study of Ayyıldiz and Karaman on "Examination of the studies on the physical properties and designs of preschool classrooms in Turkey" in 2019, the studies on the physical properties of preschool education institutions from 1989 to 2019 were examined. The results are that they are not suitable for the needs of the students, the physical equipment of the classrooms is insufficient, and the equipment and materials are both old and inadequate.

Parents' expectations and suggestions are primarily to develop a system or program for the diagnosis and education of gifted children. Early diagnosis and education are among the recommendations. It has taken its place among the suggestions on teacher education and family education. Parents emphasize 
that an education policy and system or program should be developed regarding the discovery and education of children in the earliest period. Early diagnosis is another issue that is emphasized. Teacher and family training is another topic to be considered. After a general policy and program development title for parents, it is clearly seen how important early diagnosis is. Various studies have suggested that early diagnosis and education programs for the needs of the child contribute significantly to success and reduce the risk of educational and emotional adaptation of children with different needs (Aydın \& Şentürk, 2020). Therefore, determining the needs of children in the earliest period and providing them with educational opportunities in line with their determined needs increase its importance.

\section{SUGgestion}

In this section, the following suggestions are presented in line with the research findings. An individual opens his eyes to the world with his family. The family is alone in the education of the child, especially in early childhood until pre-school education. At this point, it is important for the family to discover the gifted individuals in early childhood and to provide the necessary educational opportunities. In this regard, the following suggestions have been made for families.

- Attending marriage school before marriage,

- The expectant mothers and fathers receive expert support regarding the pregnancy and postpartum period,

- Following the postnatal child very well, recording the events such as infant reactions, making the first syllable, speaking and walking, and obtaining information about the general characteristics of gifted children in the early period,

- In addition to speaking, listening patiently and patiently giving feedback, they can do more story reading, storytelling and completion activities by keeping them away from the digital world in the first years of their child's life.

- Providing enriched educational materials in early childhood,

- Helping to dream,

- Providing an environment intertwined with nature,

- Enable hands-on experimentation

- Tending towards fun games and activities that will minimize stress and anxiety,

- Getting support from an expert working with specially gifted children,

- Introducing the expert opinion as early as possible,

- Getting pre-school education in the early period,

\section{Limitation}

This research is limited to the Opinions of 30 Parents of Specially Talented Children attending Malatya BİLSEM in 2019/2020 Academic Year.

\section{References}

Arnold, D. ve Preckel, F. (2011). Hochbegabte Kinder klug begleiten. Ein Handbuch für Eltern. Weinheim: Beltz

Aydın, S. ve Şentürk, Ş. (2020). Okul öncesi öğretmenlerinin özel yetenekli çocuklara yönelik algıları, Türkiye Sosyal Araştırmalar Dergisi Yıl: 24 sayı 2 - Ağustos 2020

Ayyıldız, E. ve Kahraman, E. (2019). Türkiye'de okul öncesi sınıflarının fiziksel özellikleri

ve tasarımları üzerine yapılmış çalışmaların incelenmesi, Medeniyet Ĕ̆itim Araştırmaları Dergisi Cilt:3, Sayı:1, 2019, s.47-60

Bolat, H. ve Yelken, T. (2020). Özel yetenekli lise öğrencilerinin aile ve okula yönelik demokratik ortam algılarının belirlenmesi, Bolu Abant İzzet Baysal Üniversitesi Eğitim Fakültesi Dergisi, 20 (1), 252-268.

Creswell, J. W. (2013). Research design: Qualitative, quantitative, and mixed methods approaches. Sage Publications.

Çavuşoğlu, M, Semerci, N. (2015). Anne Babaların BİLSEM’e Devam Eden Özel Yetenekli

Çocuklarına İlişkin Görüşleri (Bartın İli Örneği), Bartın Üniversitesi Ĕgitim Fakültesi Dergisi XIV. Uluslararası Katılımlı Sınıf Öğretmenliği Eğitimi Sempozyumu (21-23 Mayıs 2015) Özel Sayıs1 s. $325-335$

Çullu, M. ve Samanc1, O. (2016). Çocuk eğitiminde demokrasi, Erzincan Üniversitesi Sosyal Bilimler Enstitüsü Dergisi (ERZSOSDER) IX- I: 79 -84,

Denizkan, Ü. (2007). Okul öncesi eğitimde değerlendirme aracı olarak portfolyo. Gazi Eğitim Fakültesi Dergisi. 27 (1), 169-178.

Heller, K. A. ve Schofield, N. J. (2008). Identification and nurturing the gifted from an international perspective. S. Pfeiffer (Ed.) Handbook of giftedness in children (ss. 93-114). US.: Springer

Horsch, H.; Müller, G. \& Spicher, H.J. (2006): Hoch begabt - und trotzdem glücklich. Was Eltern, Kindergarten und Schule tun können, damit die klügsten Kinder nicht die

Dummen sind. Ratingen: ObersteBrink.

İpek, Y. (2019). Okul Öncesi Dönemde Özel Yetenekli Çocukların Ailelerinin Gözlemleri ve Karşılaştıkları Sorunlar. International Congress on Gifted and Talented Education, November 1-3, Inonu University, Malatya.

Knudsen, A. E. (2019): Børns hjerner. Hjerne, leg og dannelse i dagtilbud - og et opør med tanken om tvangsmodning of børn. Frederikshavn/Dänemark: Dafolo forlag.

Koop, C. \& Preckel, F. (2015). Beratungsanliegen und themen im Feld Hochbegabung. In Koop, C. \& Jacob, A. (Hrsg.), Psychologische Beratung im Feld Hochbegabung. Karg

Hefte: Beiträge zur Begabtenförderung und Begabungsforschung, 8,818 .

Koop, C. \& Welzien, S. (2010): Im Dialog mit Eltern. In Koop, C.; Schenker, I.; Müller, G.;

Welzien, S. \& KargStiftung (Hrsg.), Begabung wagen. Ein Handbuch für den Umgang mit Hochbegabung in Kindertagesstätten (S. 339345). Weimar: das netz.

Kuzgun, Y. (2003). İlköğretimde Rehberlik. Ankara: Nobel Yayın Dağıtım.

Markefka, M. ve Nave-Herz, R. (1989): Handbuch der Familien- und Jugendforschung. Band 1. Familienforschung. Neuwied

Merriam, S. (2013). Nitel araştırma desen ve uygulama için bir rehber. Ankara: Nobel Yayıncılık. 
Özkubat, S. (2013). Okul Öncesi Kurumlarında Eğitim Ortamlarının Düzenlenmesi ve Donanım, Adnan Menderes Üniversitesi Ĕ̆itim Fakültesi Eğitim Bilimleri Dergisi, Aralık 2013, 4 (2), 58-66

Preckel, F. ve Brüll, M. (2008): Intelligenztests. München: Ernst Reinhardt.

Preckel, F. ve Vock, M. (2013): Hochbegabung. Ein Lehrbuch zu Grundlagen, Diagnostik und Fördermöglichkeiten. Göttingen: Hogrefe.

Ruckdeschel, R. (2017): Von und mit Kindern lernen - MetaKognitionen in der Kindertagesstätte? In Koop, C. \& Riefling, M. (Hrsg.), Alles eine Frage der Haltung? Begabtenförderung in der Kindertagesstätte. Karg Hefte: Beiträge zur Begabtenförderung und Begabungsforschung, 10, 3037.

Rosenbaum, H. (1982). Formen der Familie. Untersuchungen zum Zusammenhang von Familienverhältnissen, Sozialstruktur und sozialem Wandel in der deutschen Gesellschaft des 19. Jahrhunderts. Frankfurt.
Saldana, J. (2019). Nitel araştırmacılar için kodlama el kitabı. (Çev. Tüfekçi, Şad ve Akcan) Ankara. Pegem Yayın Akademi.

Schneewind, K.A. (1991). Familienpsychologie. Stuttgart.

Solzbacher, C. \& Behrensen, B. (2010): Individuelle Förderung als Grundlage für

Begabtenförderung. In Koop, C.; Schenker, I.; Müller, G.; Welzien, S. \& KargStiftung (Hrsg.), Begabung wagen. Ein Handbuch für den Umgang mit Hochbegabung in Kindertagesstätten (S. 4555). Weimar: das netz.

Tanrı̈̆ğen, A., (2012). Bilimsel Araştırma Yöntemleri, Anı Yayıncılık, Ankara.

Textor, M.R. (1991). Familien: Soziologie, Psychologie. Eine Einführung für soziale Berufe. Freiburg.

Weber-Kellermann, I. (1987). Die deutsche Familie. Versuch einer Sozialgeschichte. Frankfurt 9. Auflage.

Yeşilyaprak, B. (2006). Eğitimde rehberlik hizmetleri. Ankara: Nobel Yay.

Yildirim, A. ve Şimşek, H. (2011). Sosyal bilimlerde nitel araştırma yöntemleri. Ankara: Seçkin Yayıncılık. 